\title{
Ultrasound, the handyman serving our whole populations in the post COVID-19 pandemic
}

\author{
Ultraschall, der Handwerker im Dienste der gesamten Bevölkerung \\ nach der COVID-19-Pandemie
}

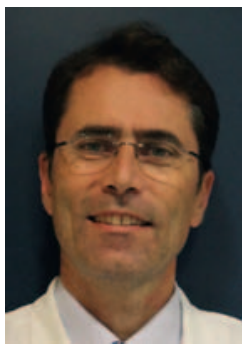

Fabio Piscaglia

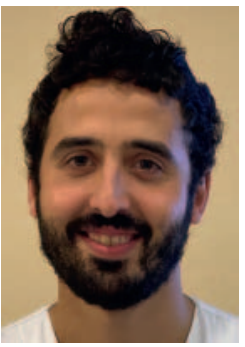

Bernardo Stefanini

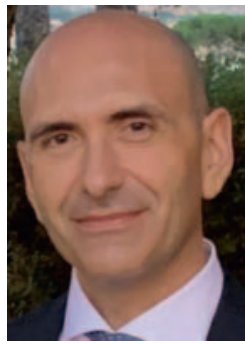

Vito Cantisani
Correspondence

Fabio Piscaglia

Alma Mater Studiorum, University of Bologna, Bologna, Italy

fabio.piscaglia@unibo.it
Bibliography

Ultraschall in Med 2021; 42: 576-578

DOI 10.1055/a-1652-7805

ISSN $0172-4614$

(C) 2021. Thieme. All rights reserved.

Georg Thieme Verlag KG, Rüdigerstraße 14,

70469 Stuttgart, Germany
Since the introduction of the B-mode technology around 40 years ago the evolution of ultrasonography has been greatest and has surpassed the evolution of other imaging methods such as Computed Tomography or Magnetic Resonance from some points of view. Ultrasound now spans through an extremely wide range of regular uses, covering needs of the entire spectrum of our citizens. The articles published in this issue of the journal are a very illustrative example of such versatility. For instance, if we consider the ages of the population, these articles show how ultrasound is regularly utilized with great benefit at any time of the human life. Its use spans from the very early times, like the prenatal intrauterine conditions [1], moving to the perinatal period [2], the adult life $[3,4]$, times at which CT or MRI are scantly of any use and finally to the disease of the elderly, such as Alzheimer's dementia [5]. Not only applications of ultrasonography cover the entire spectrum of human life in terms of time, but the size and price of the scanners range from relatively large top level scanners movable only on wheels, where the newest advanced technologies can be implemented [3] and valued over 100000 Euros, to pocket size scanners, which are conveniently utilized at the bedside [6] and easily held in one hand. The very recent technologies have even added the possibility to connect battery operated ultrasound transducers to some potent commercial smartphones in the setting of hand-held ultrasonography. This technology skips the need of dedicated scanners and may keep low the entry prices, making the ratio between the most expen- sive and the cheapest ultrasonography tools potentially larger than 100 times. Similar ranges of scanners size, capabilities and costs are not present for CT or MR. Furthermore, ultrasound has become capable not only to display morphological information, but also functional findings: for instance presence and velocity of blood flow in large vessels with Doppler, tissue stiffness with elastography [7], tissue perfusion with quantification of contrast ultrasound [8] and very recently measurement of tissue ultrasound dispersione/viscosity or quantification of liver fat content $[3,9-11]$ are almost all become potentially available in the same equipment. Beside the extension in terms of life time and types of equipments, the COVID-19 pandemic has made a reality also a larger use of ultrasound in body districts and enviromental settings. Ultrasound was known to be able to accurately investigate extremely superficial structures such as the skin with super high frequency tranducers as well as deep body regions like the heart or retroperitoneal vessels. However the use of ultrasound for pulmonary investigations was claimed to be effective, but often limited to intensive care units, not having still achieved widespread use. The need to assess Sars-Cov-2 infected patients, who often suffer primarily from a pulmonary involvement and for which there was, and still there is a need to restrict the access to hospital only to those in clear need to avoid an overwhelming of health care facilities, has put ultrasound on the stage. Lung ultrasound has in fact rapidly become part of the assessment of such patients, gaining large success [12-14]. It is relatively easy to 
learn, making physicians more confident in the decision to keep patients at home or to refer them to hospital and has become seamlessly integrated in the clinical sonographic assessment of such patients. In this issue of the journal the potential of lung ultrasound is mentioned [15]. However, we would like to draw the attention to the integration of ultrasound into the clinical assessment of patients, when utilized by physicians who are not only those performing ultrasound, but also those primarily in charge of the clinical decisions. This is the emerging concept of point-of-care ultrasound or even better of the ultrasound assisted visit of our patients, where ultrasound is utilized as an extremely valuable extension of the physicial examination, enabling doctors to take more consistent decision about the planning of the best diagnostic and therapeutical strategies for our patients. This has been defined as the Sonography-Assisted Medical Examination (SAME) $[16,17]$. An example of this concept is illustrated also in an article of the present issue [4]. Therefore also from this point of view ultrasound is showing the widest range of applications in terms of organs regularly investigated to the setting of use, spanning from top radiology enviroments with Multiparametric ultrasound, to clinical wards, to the emergency department and intensive care units to territorial services, ambulances and increasingly also the home of patients.

Altogether, after the COVID pandemic ultrasound appears to have become even more openly the medical act at the greatest service of our populations.

\section{Ultraschall, der Handwerker im Dienste der gesamten Bevölkerung nach der COVID-19-Pandemie}

Seit der Einführung des B-Mode-Verfahrens vor etwa 40 Jahren hat sich die Sonografie am stärksten weiterentwickelt und in mancher Hinsicht die Entwicklung anderer bildgebender Verfahren wie der Computertomografie oder der Magnetresonanz-Tomografie überholt. Ultraschall umfasst heute ein extrem breites Spektrum an Standardanwendungen und deckt den Bedarf unserer Bürger in ihrer ganzen Bandbreite ab. Die in dieser Ausgabe der Zeitschrift veröffentlichten Publikationen sind ein sehr anschauliches Beispiel für diese Vielseitigkeit. Betrachtet man beispielsweise das Alter der Bevölkerung, so zeigen diese Arbeiten, wie Ultraschall regelmäßig und mit großem Nutzen in jeder Lebensphase angewandt wird. Sein Einsatz erstreckt sich von den sehr frühen Phasen, wie den pränatalen intra-uterinen Erkrankungen [1], bis zur Perinatalperiode [2], dem Erwachsenenalter [3, 4], Zeiten, in denen CT oder MRT kaum von Nutzen sind, bis hin zu den Erkrankungen im Alter, wie der Alzheimer-Demenz [5]. Die sonografischen Anwendungen decken nicht nur die gesamte Zeitspanne eines menschlichen Lebens ab. Auch die Größe und der Preis der Geräte reichen von relativ großen, nur auf Rädern fahrbaren Scannern der Spitzenklasse, in denen neueste fortschrittliche Technologien zur Anwendung kommen [3] und die über $100000 €$ kosten, bis hin zu Scannern im Taschenformat, die bequem am Krankenbett eingesetzt werden [6] und die man leicht in einer Hand halten kann. In der Handsonografie ist es mit den neuesten Technologien sogar möglich, batteriebetriebene Ultraschallsonden an bestimmte leistungsstarke handelsübliche Smartphones anzuschließen. Diese Technik macht speziell dafür vorgesehene Scanner überflüssig und kann die Einstiegspreise niedrig halten, sodass das Verhältnis von den teuersten zu den billigsten Ultraschallgeräten eventuell mehr als das Hundertfache betragen kann. Ähnliche Unterschiede zwischen den Scannern bezüglich Größe, Leistung und Preis gibt es bei den CT- oder MRT-Geräten nicht. Außerdem ist die Sonografie zwischenzeitlich in der Lage, nicht nur morphologische Informationen, sondern auch funktionelle Befunde darzustellen: Zum Beispiel sind die Bestimmung des Vorhandenseins und der Geschwindigkeit des Blutflusses in großen Gefäßen mittels Doppler, der Gewebesteifigkeit mittels Elastografie [7], der Quantifizierung der Gewebeperfusion im kontrastverstärkten Ultraschall [8] und seit kurzem die Messung der Gewebe-Ultraschalldispersion/-Viskosität oder die Quantifizierung des Leberfettgehalts [3, 9-11]fast allesamt mit derselben Ausstattung möglich. Durch die COVID-19-Pandemie wurde neben der Verlängerung der Lebensdauer und der Erweiterung der Geräteausstattungen auch eine breitere Anwendung der Sonografie in den verschiedenen Körperregionen und unterschiedlichen Umfeldern ermöglicht. Ultraschall kann bekanntlich sowohl extrem oberflächliche Strukturen wie die Haut mittels Super-Hochfrequenz-Sonden als auch tiefe Körperregionen wie das Herz oder retroperitoneale Gefäße genau untersuchen. Zwar wurde behauptet, dass der Einsatz der Sonografie bei Lungenuntersuchungen effektiv sei, dieser war jedoch oft auf Intensivstationen beschränkt und fand noch keine breite Anwendung. Mit der Untersuchung von SARS-CoV-2-infizierten Patienten, bei denen in erster Linie häufig die Lunge betroffen war und bei denen es notwendig war, nur die Erkrankten mit eindeutigem Bedarf zu hospitalisieren, um eine Überlastung des Gesundheitssystems zu vermeiden, wurde der Ultraschall ins Rampenlicht gestellt. Tatsächlich wurde Lungenultraschall schnell in die Untersuchung solcher Patienten integriert und hat große Erfolge erzielt [12-14] Er ist relativ leicht zu erlernen und gibt den Ärzten mehr Entscheidungssicherheit, ob Patienten zu Hause bleiben oder ins Krankenhaus überwiesen werden sollen, und hat sich nahtlos in die klinisch-sonografische Beurteilung dieser Patienten integriert. In dieser Ausgabe der Zeitschrift wird das Potenzial des Lungenultraschalls hervorgehoben [15]. Wir möchten jedoch auf die Integration der Sonografie in die klinische Untersuchung von Patienten hinweisen, sofern diese von Ärzten gemacht wird, die nicht nur die Sonografie durchführen, sondern in erster Linie auch für die klinischen Entscheidungen verantwortlich sind. In diesem Fall handelt es sich um das sich entwickelnde Konzept des Point-ofCare-Ultraschalls oder besser noch der ultraschallgestützten Untersuchung unserer Patienten, bei der die Sonografie eine äußerst wertvolle Ergänzung der körperlichen Untersuchung ist, die es den Ärzten ermöglicht, konsequentere Entscheidungen über die Planung der besten diagnostischen und therapeutischen Strategien für unsere Patienten zu treffen. Dies wurde als Sonografie-gestützte medizinische Untersuchung („Sonography-assisted medical Examination“ SAME) definiert [16, 17]. Dieses Konzept wird auch in einem Artikel in dieser Ausgabe vorgestellt [4] Daher zeigt der Ultraschall auch unter diesem Gesichtspunkt das breiteste Anwendungsspektrum. Dies betrifft sowohl die 
regelmäßig untersuchten Organe als auch das Einsatzgebiet, das von der Spitzenradiologie mit multiparametrischem Ultraschall, über die Klinikstationen, die Notaufnahme und die Intensivstationen bis zu den lokalen Rettungsdiensten, Ambulanzen und zunehmend auch bis ins das Zuhause der Patienten reicht.

Insgesamt hat der Ultraschall nach der COVID-Pandemie offenbar noch größere Fortschritte gemacht und ist zu einer medizinischen Maßnahme im Dienste unserer Bevölkerung geworden.

\section{Conflict of Interest}

COI for companies related to imaging. Honoraria for: Speaker bureau from Bayer, ESAOTE, Samsung; Consultancy: GE, Bracco. Advisory Board travel support: Siemens Healthineers.

\section{References}

[1] Deng Y, Jin Y, Xu R et al. Fetal Hemodynamic Response to Maternal Oxygenation in Normal and Complicated Pregnancies. Ultraschall in Med 2020. doi:10.1055/a-1187-1459. Epub ahead of print. PMID: 32971542.

[2] Sande R, Jenderka KV, Moran CM et al. Safety Aspects of Perinatal Ultrasound. Ultraschall in Med 2021. doi:10.1055/a-1538-6295. Epub ahead of print. PMID: 34352910

[3] Bae JS, Lee DH, Lee JY et al. Quantitative Assessment of Fatty Liver using Ultrasound with Normalized Local Variance Technique. Ultraschall in Med 2020. doi:10.1055/a-1143-3091. Epub ahead of print. PMID: 32323278.

[4] Nazerian P, Gigli C, Donnarumma E et al. Diagnostic Accuracy of Point-ofCare Ultrasound Integrated into Clinical Examination for Acute Diverticulitis: A Prospective Multicenter Study. Ultraschall in Med 2020. doi:10.1055/a-1161-0780. Epub ahead of print. PMID: 32688404.

[5] Yilmaz R, Granert O, Schäffer E et al. Transcranial Sonography Findings in Alzheimer's Disease: A New Imaging Biomarker. Ultraschall in Med 2020. doi:10.1055/a-1146-3036. Epub ahead of print. PMID: 32492728.

[6] Fröhlich E, Beller K, Muller R et al. Point of Care Ultrasound in Geriatric Patients: Prospective Evaluation of a Portable Handheld Ultrasound Device. Ultraschall in Med 2020; 41: 308-316. doi:10.1055/a-0889-8070. Epub 2019 Apr 26. PMID: 31026863.

[7] Săftoiu A, Gilja OH, Sidhu PS et al. The EFSUMB Guidelines and Recommendations for the Clinical Practice of Elastography in Non- Hepatic Applications: Update 2018. Ultraschall in Med 2019; 40: 425-453. doi:10.1055/a-0838-9937. Epub 2019 Jun 25. PMID: 31238377.
[8] Maxeiner A, Fischer T, Schwabe J et al. Contrast-Enhanced Ultrasound (CEUS) and Quantitative Perfusion Analysis in Patients with Suspicionfor Prostate Cancer. Ultraschall in Med 2019; 40: 340-348. doi:10.1055/ a-0594-2093. Epub 2018 Jun 6. PMID: 29874683.

[9] Ferraioli G, Berzigotti A, Barr RG et al. Quantification of Liver Fat Content with Ultrasound: A WFUMB Position Paper. Ultrasound Med Biol 2021; 47: 2803-2820. doi:10.1016/j.ultrasmedbio.2021.06.002. Epub 2021 Jul 18. PMID: 34284932.

[10] Dioguardi Burgio M, Imbault M, Ronot M et al. Ultrasonic Adaptive Sound Speed Estimation for the Diagnosis and Quantification of Hepatic Steatosis: A Pilot Study. Ultraschall in Med 2019; 40: 722-733. doi:10.1055/a-0660-9465. Epub 2018 Nov 5. PMID: 30396216.

[11] Jesper D, Fiedler S, Klett D et al. Shear Wave Dispersion Imaging for the Characterization of Focal Liver Lesions - A Pilot study. Ultraschall in Med 2021. doi:10.1055/a-1610-9171. Epub ahead of print. PMID: 34614516.

[12] Piscaglia F, Stefanini F, Cantisani V et al. Benefits, Open questions and Challenges of the use of Ultrasound in the COVID-19 pandemic era. The views of a panel of worldwide international experts. Ultraschall in Med 2020; 41: 228-236. doi:10.1055/a-1149-9872. Epub 2020 Apr 15. PMID: 32294795.

[13] Volpicelli G, Gargani L, Perlini S et al. Lung ultrasound for the early diagnosis of COVID-19 pneumonia: an international multicenter study. Intensive Care Med 2021; 47: 444-454. doi:10.1007/s00134-02106373-7. Epub 2021 Mar 20. PMID: 33743018; PMCID: PMC7980130.

[14] Karp J, Burke K, Daubaras SM et al. The role of PoCUS in the assessment of COVID-19 patients. J Ultrasound 2021; 19: 1-9. doi:10.1007/s40477-02100586-8. Epub ahead of print. PMID: 33870480; PMCID: PMC8053566.

[15] Tung Chen Y, Martí de Gracia M, Parra Gordo ML et al. Lung Ultrasound Findings in a COVID-19 Patient with Negative Chest CT. Ultraschall in Med 2020. doi:10.1055/a-1248-9068. Epub ahead of print. PMID: 32987432

[16] Schiavone C, Grassi R, Bertolotto M et al. The sonographic medical act. J Ultrasound 2020; 23: 445-447. doi:10.1007/s40477-020-00518-y. Epub 2020 Sep 23. PMID: 32968963; PMCID: PMC7588558.

[17] Cantisani V, lannetti G, Miele V et al. Addendum to the sonographic medical act. J Ultrasound 2021; 24: 229-230. doi:10.1007/s40477-02100603-w. Epub 2021 Jul 9. PMID: 34241829; PMCID: PMC8363678. 